\title{
The Effects of E-Services on Revenue Collection and Tax Compliance among SMEs in Developing Countries: A Case Study of Zambia
}

\author{
Vernon Mukuwa ${ }^{1}$, Jackson Phiri² \\ ${ }^{1}$ Graduate School of Business, University of Zambia, Lusaka, Zambia \\ ${ }^{2}$ Department of Computer Sciences, School of Natural Sciences, University of Zambia, Lusaka, Zambia \\ Email:vernon.mukuwa@gmail.com, jackson.phiri@cs.unza.zm
}

How to cite this paper: Mukuwa, V. and Phiri, J. (2020) The Effects of E-Services on Revenue Collection and Tax Compliance among SMEs in Developing Countries: A Case Study of Zambia. Open Journal of Social Sciences, 8, 98-108. https://doi.org/10.4236/jss.2020.81008

Received: November 29, 2019

Accepted: January 10, 2020

Published: January 13, 2020

Copyright ( 2020 by author(s) and Scientific Research Publishing Inc. This work is licensed under the Creative Commons Attribution International License (CC BY 4.0).

http://creativecommons.org/licenses/by/4.0/ (c) (i) Open Access

\begin{abstract}
World over, taxpayers' resistance, underutilization and reluctance to use e-services remain a great concern and still plague various tax agencies which are embracing electronic tax services. This study set out to investigate the effects of these electronic services on revenue collection and tax compliance among Small and Medium Enterprises in urban Zambia. The study also sought to identify factors that influence the acceptance and use of electronic services among SMEs using the Unified Theory of Acceptance and Use of Technology (UTAUT) Model. The study employed a descriptive research design where 400 questionnaires were administered to purposively sampled SMEs in the Copper belt and Lusaka provinces. The data collected was analyzed using the social package for statistical sciences software (SPSS) descriptive and correlation analysis. The descriptive analysis revealed that there has been a significant increase in revenue collection and tax compliance among SMEs since the introduction of these e-services. This was validated by results from correlation analysis which gave a correlation coefficient of 0.157 and a p-value of 0.017 , which was deemed to be statistically significant because it gave a p-value less than 0.05 . The study also shows that Performance Expectancy, Effort Expectancy and Social Influence affect SMEs' behavioral intention to use eservices. Further, only Behavioral Intentions of SMEs significantly affect their use behavior of e-services.
\end{abstract}

\section{Keywords}

Tax Online, Technology Acceptance, E-Services, SMEs, Tax Compliance

\section{Introduction}

There is an increasing need by governments to collect more revenue by way of 
taxes to face the increasing financial expenditures budgeted by the country. Automated systems have been proven to be capable of introducing massive efficiencies to business processes that can result in increased revenue collections [1]. Revenue administration modernization has a positive impact on the cost of tax administration and effectiveness of revenue collection. The Zambian government embarked on a modernization program for the Zambia Revenue Authority (ZRA). In 2013, they launched an ICT based business solution called Tax Online for the Domestic Taxes Division. The ZRA then introduced electronic payments in 2014 to help taxpayers pay their taxes electronically. These systems were aimed at reducing the cost of tax compliance on the part of taxpayers, provision of better services to taxpayers and increased tax compliance among taxpayers which would in turn increase revenue collection. Despite all the efforts aimed at developing better and easier electronic tax filing system, the system still remains unnoticed by the public, especially small business owners. This is demonstrated by the long queues observed at ZRA offices for return filing and payment during peak periods.

The paper looks at the effects of e-services on revenue collection and tax compliance among Small and Medium Enterprises (SMEs) in urban Zambia. The study further examines the applicability of the Unified Theory of Acceptance and Use of Technology (UTAUT) model in Zambia. The rest of the paper is arranged as follows: in Section 2, the literature review is given. In Section 3, the research methodology is presented. The research results and conclusions are given in Sections 4 and 5 respectively.

\section{Literature Review}

Defining SMEs is problematic because of their diversity. Different writers adopt different definitions based on the criteria appropriate for their study. It is often said and believed that SMEs significantly differ from large firms in terms of their financial decisions and behavior. In Zambia, SMEs are usually defined as any business whose annual turnover is less than $\mathrm{K}$ 800,000 (approximately US $\$ 61,500)$. This is the definition the researcher adopted for the study. SMEs largely operate in the informal sector and create significant employment in addition to generating significant output. Because they operate from the informal sector, tax compliance among SMEs has been low. Developing countries continue to face challenges of tax evasion and non-compliance in the informal sector [2]. It is for this reason that ZRA embarked on tax reforms.

E-services refer to the online tax systems where taxpayers are able to interact, negotiate and pay their taxes. Like all other tax reforms, e-services were implemented to enhance performance in revenue administration by: providing readily accessible historical data because the system is web based; reducing errors, processing times and costs; improving taxpayer service and promoting voluntary compliance and hence increasing revenue collections-largely by making it more user friendly and convenient to file tax returns and pay any amounts due; minimizing rent seeking opportunities by decreasing the level of interaction be- 
tween taxpayers and revenue administration staff; and aiding better decision-making [3] [4]. A study was done on e-tax systems adoption in Zambia. This study showed that e-tax is useful, easy to use and secure [5]. Another study was conducted on the Influence of Electronic Tax Filing System on Tax Compliance and Tax Collection, this study set out to investigate the influence of the electronic tax filing system on tax compliance and tax collection. Findings from the study show that the electronic tax filing system has the potential of increasing tax compliance and revenue collection [6]. Findings from a similar study indicated that $75 \%$ of the respondents were of the opinion that electronic tax register machines have helped to curb cases of tax evasion, $86 \%$ of the respondents were of the opinion that electronic tax register has helped increase revenue collection due to their efficient nature [7].

Tax compliance has been defined as paying taxes on time and timely reporting of correct tax information [8]. Therefore, tax compliance means seeking to pay the right amount of tax in the right place at the right time. Where right means that the economic substance of the transaction undertaken coincides with the place and form in which they are reported for tax purposes. Tax compliance is categorized into three multi-faceted components; return filling, reporting correct assessments and making correct payments on time [9]. Tax compliance is the value of the taxpayer's own time and resources along with any out of pocket costs paid to the tax preparers and other advisors, invested to ensure compliance with the laws [10]. It is asserted that tax compliance is the provision of tax information at the proper time and ensuring returns accurately report tax liability [11].

A number of technology acceptance models and theories have been applied to different phenomena and varying cultural settings in many studies, producing varying results. For example, in a study on the factors driving the adoption of E-banking services in Zambia based on the UTAUT Model, it was revealed that the UTAUT factors; performance expectancy, effort expectancy, facilitating conditions and behavior intention have a significant impact in the adoption of e-banking services. Social influence was non-significant to the user's intention to adopt e-banking services [12]. Some of the results from these studies are consistent with the original postulations while others contradict them. Eight technology acceptance models were combined by Venkatesh et al. to formulate the UTAUT model [13]. It is often argued that the UTAUT model is able to explain $70 \%$ of the variance in usage intention, which is significant compared to the actual eight models used to build it. There is still lack of research about the effects of e-services on revenue collection and tax compliance. Further there is no research on the applicability of the UTAUT model on the adoption of e-services by SMEs in urban Zambia. This research plans to fill these gaps.

\section{Methodology}

The research adopted the descriptive research design to help analyze the relationship between e-services and tax compliance. The study population was 
composed of 127,510 SMEs registered with ZRA and based in urban areas. Lusaka and Ndola cities were specifically sampled for this study as they accounted for $49 \%$ of these SMEs. Due to the nature of the study, the purposive sampling technique was employed. The sample size was determined using the Taro Yamane (1967) formula which gives a 95\% confidence level. The formula is as shown:

$$
n=N / 1+N(e)^{2}
$$

where; $n=$ the required sample size, $N=$ the number of SMEs in the population and $e=$ the allowable error (\%). Substituting numbers in the formula gives us:

$$
N=127510 / 1+127510 \times(0.05)^{2}
$$

A total of 400 questionnaires were distributed to SMEs in Lusaka and Ndola out of which a positive response on 229 was received for analysis. The researcher considered this as a success since it represented $57 \%$ of the sample size that was selected for the study. A response rate of $50 \%$ is adequate, any response not exceeding $60 \%$ and greater than $50 \%$ is good, and a response rate above $69 \%$ is very high [14]. Data analysis was undertaken using the Statistical Package for Social Scientists (SPSS) software where the hypotheses of the study were tested. Correlation and descriptive analysis were used to test the effects of e-services on tax compliance and revenue collection among SMEs in urban Zambia.

\subsection{Research Model}

The research also sought to determine the applicability of the UTAUT model on SMEs' intention to accept and use e-services for their tax obligations. The model, developed by Venkatesh et al. in 2003 has four independent variables and two dependent variables. The model also has what its authors referred to as moderating variables; however, these have been excluded in this study (Figure 1).

\subsection{Research Hypotheses}

The researcher used the following research hypotheses:

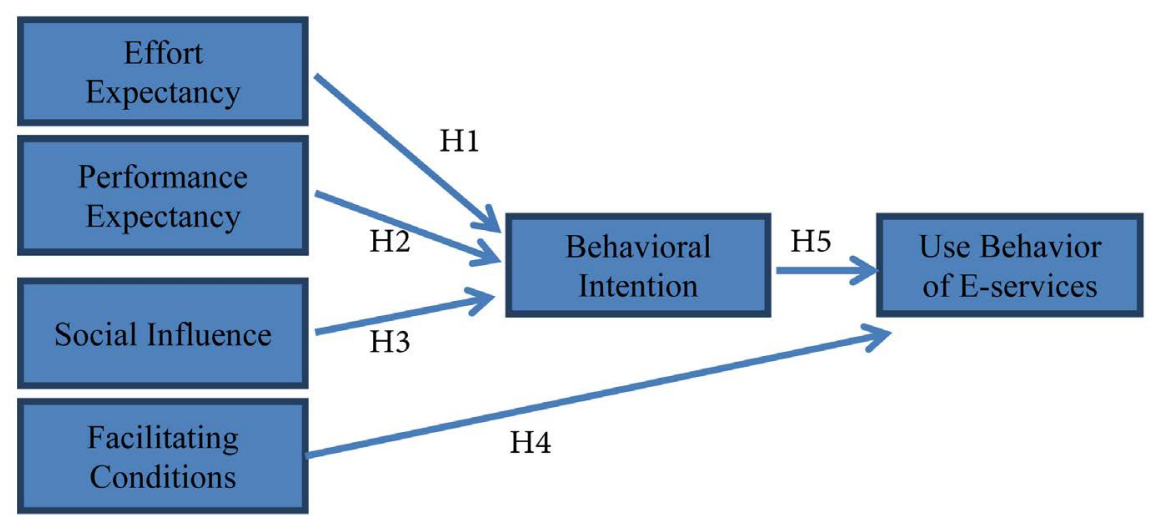

Figure 1. The proposed research model based on the UTAUT model by Venkatesh et al. (2003). 
- H1: Effort expectancy positively influences behavioral intentions for SMEs to use e-services. It is expected that increased levels of ease of use of e-services will increase the behavioral intention to use e-services hence this hypothesis.

- H2: Performance expectancy positively influences SMEs' behavioral intention to use e-services. It is expected that an efficient and more productive system will increase the behavioral intention to use e-services hence the hypothesis.

- H3: Social influence conditions positively influence behavioral intentions for SMEs to use e-services. A person's behavioral intention to use e-services depends on how they are viewed by others hence this hypothesis.

- H4: Facilitating conditions directly influence SMEs' use behavior of e-services. It is generally expected that consistent support to SMEs on the use of e-services will directly influence their use behavior hence this hypothesis.

- H5: Behavior intentions directly influence SMEs' usage behavior of e-services.

\subsection{Model Testing}

Pearson's correlation analysis was used for hypothesis testing. This was done using SPSS to test if there is a linear relationship between the dependent and independent variables. A Sig value below 0.05 indicates that there is a significant relation between the dependent and independent variable whereas a Sig value above 0.05 indicates that there is no relationship between the dependent and independent variable.

\section{Results}

\section{Analysis of Demographics}

From the data that was collected, $36 \%$ of the respondents were female and $64 \%$ were male. This shows that both genders were well represented in the sample (Figure 2).

To evaluate the reliability of the questionnaire responses, the researcher sought to establish the education level of the respondents. $88 \%$ of them had been through tertiary education and $7 \%$ through secondary education. This shows that the responses can be relied on (Figure 3).

From the research data, $51 \%$ of the respondents indicated that they have been in business for more than three years. 34\% had only been in business for one year or less and $15 \%$ had been in business for two to three years. Additionally, $41 \%$ of the respondents had used e-services for more than 18 months, $30 \%$ had used them for six to eighteen months and $29 \%$ had used e-services for less than six months. This indicated that most of the respondents were acquainted with ZRA e-services (Figure 4 and Figure 5).

\section{Effects of e-services on revenue collection and tax compliance}

In order to establish the effects of e-services on tax compliance among SMEs, using a Likert Scale, the researcher asked the tax payers to indicate their views on whether e-services have improved tax compliance. The scale was done on a range from A to E; with A being Strongly Agree, C being the Midpoint while E was Strongly Disagree. The results are presented in Table 1. 


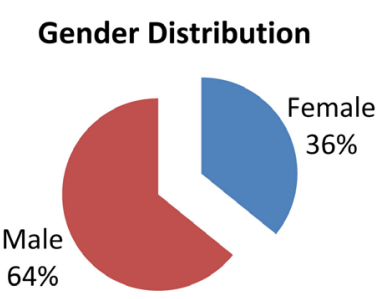

Figure 2. Gender distribution.

\section{Education Level}

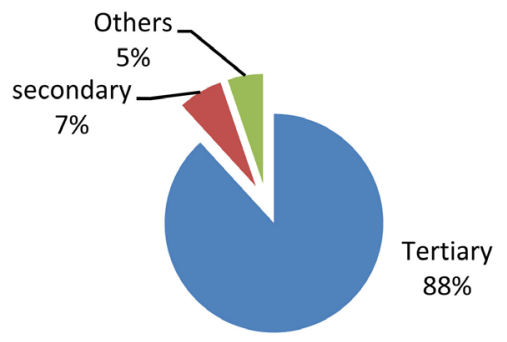

Figure 3. Education level.

\section{Duration in Business}

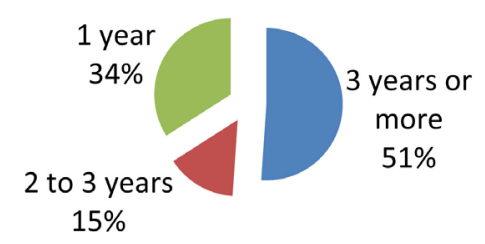

Figure 4. Duration in business.

\section{Period of System Use}

0 to 6

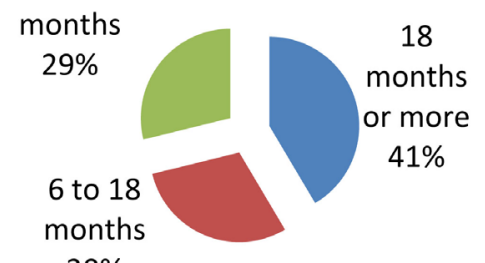

$30 \%$

Figure 5. Period of system use.

Table 1. E-Services and tax compliance.

\begin{tabular}{ccccc}
\hline & Frequency & Percent & Valid Percent & Cumulative Percent \\
\hline Strongly agree & 39 & 17 & 17 & 17 \\
Agree & 120 & 52.4 & 52.4 & 69.4 \\
Neutral & 62 & 27.1 & 27.1 & 96.5 \\
Disagree & 4 & 1.7 & 1.7 & 98.3 \\
Strongly disagree & 4 & 1.7 & 1.7 & 100 \\
Total & 229 & 100 & 100 & \\
\hline
\end{tabular}


Table 1 indicates that $69.4 \%$ of the participants believe that e-services have improved tax compliance. $27.1 \%$ are not sure what effect e-services have had on tax compliance whereas only $3.4 \%$ believe that e-services have not improved tax compliance. The researcher further sought to establish why taxpayers believe these e-services have improved compliance among SMEs. The results are shown in Table 2 .

Results from Table 2 indicate that the cost of compliance has reduced among SMEs as $69.9 \%$ of the participants either agree or strongly agree. The manual system required taxpayers to physically visit ZRA offices to file their returns and make payment. This meant that taxpayers would incur transport and time related costs. With the introduction of e-services, taxpayers can file their returns and make payment from anywhere as long as they have internet connection. $22.3 \%$ of the participants are not sure if e-services have reduced the cost of compliance whereas only $7.8 \%$ disagree with this notion.

To further establish if the introduction of e-services has improved tax compliance among SMEs, the cost of compliance and the level of compliance variables were picked and analyzed using Pearson's correlation coefficient. The correlation coefficient measures linear correlations between two variables where 1 denotes total positive correlation, -1 denotes total negative correlation and 0 denotes zero correlation. The results of this analysis are presented in Table 3.

It is generally accepted in statistical research that if the p-value (Sig) of the independent variable is smaller than 0.05 then it can be used to predict the

Table 2. E-services and cost of compliance.

\begin{tabular}{ccccc}
\hline & Frequency & Percent & Valid Percent & Cumulative Percent \\
\hline Strongly agree & 55 & 24 & 24 & 24 \\
Agree & 105 & 45.9 & 45.9 & 69.9 \\
Neutral & 51 & 22.3 & 22.3 & 92.1 \\
Disagree & 14 & 6.1 & 6.1 & 98.3 \\
Strongly disagree & 4 & 1.7 & 1.7 & 100 \\
Total & 229 & 100 & 100 &
\end{tabular}

Table 3. Correlation between e-services and tax compliance.

\begin{tabular}{cccc}
\hline & & Compliance & Cost of Tax Compliance \\
\hline & Pearson Correlation & 1 & $0.157^{\star}$ \\
Compliance & Sig. (2-tailed) & & 0.017 \\
& $\mathrm{~N}$ & 229 & 229 \\
& Pearson Correlation & $0.157^{*}$ & 1 \\
Cost of Tax Compliance & Sig. (2-tailed) & 0.017 & \\
& $\mathrm{~N}$ & 229 & 229 \\
\hline
\end{tabular}

${ }^{*}$ Correlation is significant at the 0.05 level (2-tailed). 
dependent variable. The p-value in this analysis is 0.017 which is less than 0.05 . This therefore implies that the introduction of e-services has improved tax compliance because it reduces the cost of tax compliance for SMEs. This result is consistent with Yilmaz and Coolidge (2013) whose study found that e-services reduce the cost of tax compliance ultimately improving tax compliance [15].

The applicability of the UTAUT Model in the adoption of e-services among SMEs

As shown in Figure 6 and Figure 7, there has been a significant improvement in the uptake of e-services since they were introduced by ZRA. An analysis of Figure 6 indicates that e-returns only accounted for 55\% of the total tax returns in 2014 but this drastically changed by 2017 where e-returns accounted for $97 \%$ of the total tax returns. Similarly, an analysis of Figure 7 reveals that e-payments accounted for less than $1 \%$ of the total tax revenue in 2014 but this significantly changed by 2017 where e-payments accounted for $73 \%$ of the total tax revenue. The researcher however used the UTAUT model to understand factors that influence the acceptance and adoption of these e-services among SMEs in urban Zambia.

A Pearson Correlation analysis was conducted using SPSS in order to check if there is a linear relationship between the dependent and independent variables. Table 4 presents a summary of this correlation analysis.

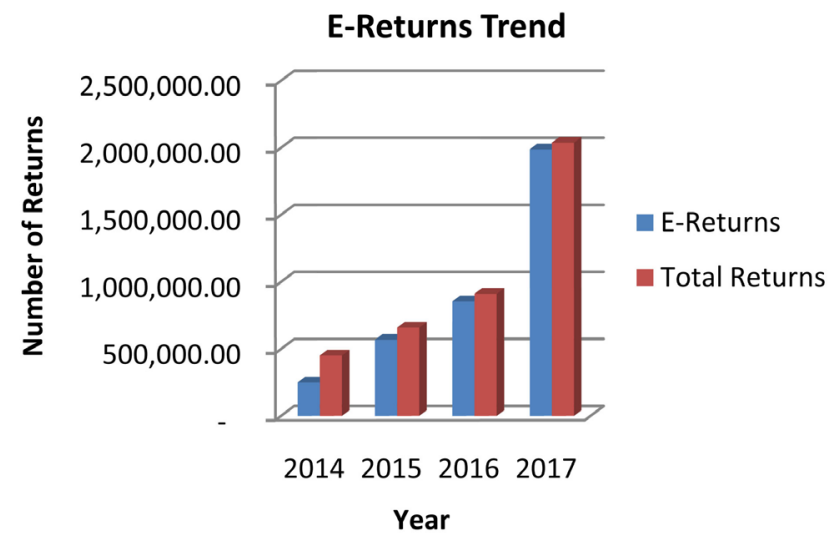

Figure 6. Electronic returns trend.

\section{E-Payments Trend}

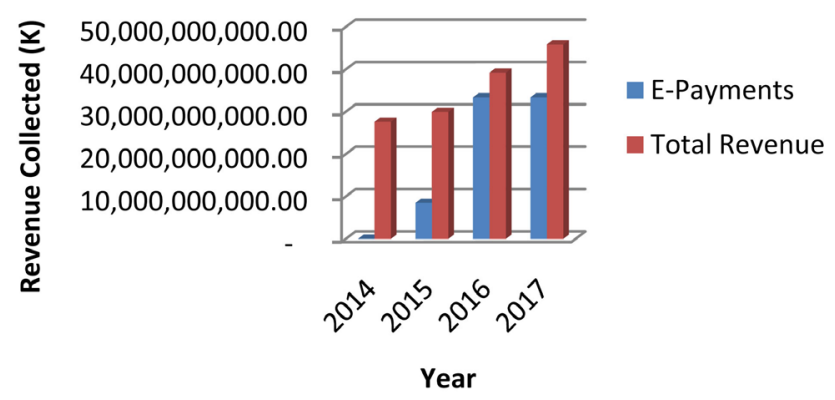

Figure 7. Electronic payments trend. 
Table 4. SPSS coefficients results summary.

\begin{tabular}{cccc}
\hline Hypothesis & Path & $\begin{array}{c}\text { Correlation } \\
\text { Coefficient }\end{array}$ & $\begin{array}{c}\text { Sig. } \\
\text { (2-tailed) }\end{array}$ \\
\hline H1 & Effort Expectancy - Behavioral Intention & $0.552^{* *}$ & 0.000 \\
H2 & Performance Expectancy - Behavioral Intention & $0.492^{* *}$ & 0.000 \\
H3 & Social Influence - Behavioral Intention & $0.329^{* *}$ & 0.000 \\
H4 & Facilitating Conditions - Use behavior of E-Services & 0.083 & 0.210 \\
H5 & Behavioral Intention - Use behavior of E-Services & $0.516^{* *}$ & 0.000 \\
\hline
\end{tabular}

A review of the results in Table 4 indicates that Effort Expectancy, Performance Expectancy and Social Influence had a Sig value lower than 0.05 which implies that they all have a significant predicative ability for the dependent variable, and therefore have an impact on SME's behavioral Intention to use e-services. These results are consistent with the original postulates by Venkatesh et al. (2003) and the results by Ayankule and Alan (2013) [16]. Results from Table 4 further reveal that Facilitating Conditions had a Sig value exceeding 0.05 implying that there is no significant linear relationship between this variable and SMEs' usage behavior of e-services. This result is inconsistent with findings by Venkatesh et al. (2003) but consistent with the results by Ayankule and Alan (2013). Results in Table 4 also reveal that Behavioral Intention has a Sig value less that 0.05 and a correlation coefficient of 0.516 implying that this variable has a significant relationship with SMEs' usage behavior of e-services a result which is inconsistent with findings by Venkatesh et al. (2003) and the results by Ayankule and Alan (2013). The results of the hypotheses testing are summarized in Table 5.

\section{Conclusion}

This study provides insights into the effects of e-services on revenue collection and tax compliance among SMEs in urban Zambia. Further, it shows the applicability of the UTAUT model on the use and adoption of these e-services among SMEs in urban Zambia. The study concludes that e-services have improved compliance among SMEs thereby increasing revenue collection. This is supported by the increase in the number of tax returns filled and the revenue collected by the revenue authority as shown in Figure 6 and Figure 7 respectively. On the applicability of the UTAUT model by Venkatesh et al. (2003), the study concludes that of the hypotheses stated, Effort Expectancy, Performance Expectancy and Social Influence significantly influence Behavioral Intentions for SMEs to use e-services while Facilitating Conditions were found to have an insignificant effect on SMEs' use behavior of e-services. Behavioral Intention, on the other hand, was found to have a significant effect on SMEs' use behavior of these e-services.

\section{Limitations of the Study}

It is known that e-services were not only introduced for SMEs but for all taxpayers 
Table 5. Hypothesis testing results summary.

\begin{tabular}{ll}
\hline \multicolumn{1}{c}{ Hypothesis } & Result \\
\hline $\begin{array}{l}\text { H1: Effort expectancy positively influences behavioral intentions for } \\
\text { SMEs' to use e-services. }\end{array}$ & Accepted \\
$\begin{array}{l}\text { H2: Performance expectancy positively influences behavioral intentions for } \\
\text { SMEs to use e-services. }\end{array}$ & Accepted \\
$\begin{array}{l}\text { H3: Social influence conditions positively influence behavioral intentions for } \\
\text { SMEs to use e-services. }\end{array}$ & Accepted \\
H4: Facilitating conditions directly influence SMEs' use behavior of e-services. & Rejected \\
H5: Behavioral intentions directly influence SMEs' usage behavior of e-services. & Accepted \\
\hline
\end{tabular}

regardless of size and whether the business operates from an urban or rural area. These could be pointed out as the limitations of this study. It is therefore recommended that future works should cover other categories of taxpayers. Despite these limitations, the researcher ensured that care is taken so that the results presented were as accurate as possible.

\section{Acknowledgements}

The authors wish to acknowledge all those who took part in the study.

\section{Conflicts of Interest}

The authors declare no conflicts of interest regarding the publication of this paper.

\section{References}

[1] Zhou, G. and Madhikeni, A. (2013) Systems, Processes and Challenges of Public Revenue Collection in Zimbabwe. American International Journal of Contemporary Research, 3, 49-60.

[2] Masarirambi, C. (2013) An Investigation into the Factors Associated with Tax Evasion in the Zimbabwe Informal Sector. ZOU, Harare.

[3] Smith, W.H. (1969) Automation in Tax Administration. Law and Contemporary Problems, 34, 751-768. https://doi.org/10.2307/1190909

[4] Chatama, Y.J. (2013) The Impact of ICT on Taxation: The Case of Large Taxpayer Department of Tanzania Revenue Authority. Developing Country Studies, 3, 91-100.

[5] Soneka, P. and Phiri, J. (2019) A Model for Improving E-Tax Systems Adoption in Rural Zambia Based on the TAM Model. Open Journal of Business and Management, 7, 908-918. https://doi.org/10.4236/ojbm.2019.72062

[6] Muwonge, H. (2011) The Influence of Electronic Tax Filing System on Tax Compliance and Tax Collection. Nairobi.

[7] Sagas, C., Nelimalyani, M. and Kosgeikimaiyo, E. (2015) An Assessment of the Impact of Electronic Tax Register on Revenue Collection by Kenya Revenue Authority Western Region, Kenya. ZENITH International Journal of Business Economics \& Management Research, 5, 111-118.

[8] Harvard Law School (2000) Comparative Tax Administration. IFK Government 
School, United States of America.

[9] Brown, R.E. and Mazur, M.J. (2003) Internal Revenue Service Comprehensive Approach to Compliance Measurement. IRS White Paper, Cambridge University Press, Washington DC.

[10] Holtzman, Y. (2007) Challenges in Achieving Transparency, Simplicity and Administering of United States Tax Code. Journal of Management Development, 126, 418-427. https://doi.org/10.1108/02621710710748257

[11] Carroll, J. (1987) Compliance with the Law. Journal of Law and Human Behavior, 11, 319-335. https://doi.org/10.1007/BF01044744

[12] Daka, G.C. and Phiri, J. (2019) Factors Driving the Adoption of E-Banking Services Based on the UTAUT Model. International Journal of Business and Management, 14, 43-52. https://doi.org/10.5539/ijbm.v14n6p43

[13] Venkatesh, V.M. (2003) User Acceptance of Information Technology: Toward a Unified View. MIS Quarterly, 27, 425-478. https://doi.org/10.2307/30036540

[14] Mugenda, O.M. and Mugenda, A.G. (2003) Research, Qualitative and Quantitative Approaches. ACTS Press, Nairobi.

[15] Coolidge, J. and Yilmaz, F. (2014) Does E-Filing Reduce Tax Compliance Costs in Developing Countries? Investment Climate in Practice, No. 21. World Bank Group, Washington DC. https://openknowledge.worldbank.org/handle/10986/20428

[16] Taiwo, A.A. and Downe, A.G. (2013) The Theory of User Acceptance and Use of Technology (UTAUT): A Meta-Analytic Review of Empirical Findings. Journal of Theoretical and Applied Information Technology, 49, 48-58. 